\title{
cfos and cjun antisense oligonucleotides block mitogenesis triggered by fibroblast growth factor-2 and ACTH in mouse Y1 adrenocortical cells
}

\author{
C F P Lotfi and $\mathbf{H}$ A Armelin \\ Departamento de Bioquímica, Instituto de Química, Universidade de São Paulo, São Paulo, Brazil \\ (Requests for offprints should be addressed to H A Armelin, Departamento de Bioquímica, Instituto de Química, Universidade de São Paulo, \\ São Paulo, 05508-900, Brazil; Email: haarmeli@quim.iq.usp.br)
}

\begin{abstract}
In $\mathrm{G}_{0} / \mathrm{G}_{1}$ cell cycle-arrested mouse $\mathrm{Y} 1$ adrenocortical cells, short pulses ( $30 \mathrm{~min}$ to $2 \mathrm{~h}$ ) of fibroblast growth factor-2 (FGF2) (5 pM to $1 \mathrm{nM}$ ) caused induction of cFos protein by $2 \mathrm{~h}$ and onset of DNA synthesis stimulation by 8-9 h. FGF2 dose-response curves for cFos induction (percent labeled nuclei with a specific anti-cFos antibody) and DNA synthesis stimulation (bromodeoxyuridine labeling index) were linearly correlated with a correlation coefficient of 0.969. Inhibition of cFos and cJun protein induction with antisense oligodeoxynucleotides (ODNs) to cfos and cjun mRNAs blocked DNA synthesis
\end{abstract}

stimulation by FGF2. Pulses (up to $2 \mathrm{~h}$ ) of synthetic $\mathrm{ACTH}_{39}(1 \mathrm{pM}$ to $1 \mathrm{nM})$ and natural porcine corticotropin A (10 $\mathrm{pg} / \mathrm{ml}$ to $1 \mu \mathrm{g} / \mathrm{ml})$ also induced cFos protein and DNA synthesis in $G_{0} / G_{1}$-arrested $Y 1$ adrenal cells. ACTH dose-response curves for $c$ Fos induction and DNA synthesis stimulation were not correlated. But cfos and/or cjun antisense ODNs blocked DNA synthesis stimulation by ACTH. Thus, signals initiated in FGF2 and ACTH receptors appear to converge to the induction of cfos and cjun genes to trigger DNA synthesis stimulation.

Journal of Endocrinology (2001) 168, 381-389

\section{Introduction}

The molecular mechanisms by which adrenocorticotropin (ACTH) causes its growth effects on adrenal cortex remained obscure for decades. In the intact organism ACTH seems to be a mitogen, but in cell lines and primary cultures of mouse, rat, cow and human adrenocortical cells ACTH appears to be a growth inhibitory hormone (Hornsby 1985).

We recently reported, for the first time, that short pulses of ACTH trigger a mitogenic response in $\mathrm{G}_{0} / \mathrm{G}_{1}$-arrested Y1 adrenocortical cells, resembling fibroblast growth factor-2 (FGF2), albeit with a reduced intensity (Armelin et al. 1996, Lotfi et al. 1997). These observations suggested that the mouse Y1 adrenocortical cell line (Yasumura et al. 1966, Schimmer 1981) is a cell system experimentally useful to access cellular and molecular mechanisms of growth control activated by ACTH receptors in adrenocortical cells.

Both ACTH and FGF2, respectively, induce the fos and jun genes in $G_{0} / G_{1}$-arrested $Y 1$ adrenocortical cells (Kimura \& Armelin 1990, Kimura et al. 1993, Lotfi et al. 1997), following the same pattern of induction displayed by $G_{0}$-arrested Balb3T3 fibroblasts stimulated by FGF2. Fos (cFos, FosB, Fra1 and Fra2) and Jun (cJun, JunB and
JunD) proteins dimerize via a leucine zipper domain to form heterodimers (Fos-Jun) and homodimers (Jun-Jun), making up the series of transcription factors denominated AP1 (for review see Angel \& Karin 1991). AP1 factors seem to play a critical role in the control of $G_{0} \rightarrow G_{1} \rightarrow S$ transition of the cell cycle. Quiescent $\mathrm{G}_{0}$-arrested fibroblasts exhibit very low levels of AP1 factors and upon stimulation by peptide growth factors, like FGF2 and platelet-derived growth factor, rapidly induce the fos and jun genes in an ordered fashion (Kovary \& Bravo 1991a,b, Cook et al. 1999). Blocking of cFos and cJun proteins induction with an antisense technique (Holt et al. 1986, Nishikura \& Murray 1987) or their activities with specific antibodies (Riabowol et al. 1988, Kovary \& Bravo 1991b) is sufficient to block the $G_{0} \rightarrow G_{1} \rightarrow S$ transition in $G_{0^{-}}$ arrested fibroblasts stimulated with growth factors.

In this paper we show that blocking $\mathrm{cFos}$ and cJun protein synthesis with antisense phosphorotioate oligodeoxynucleotides (ODNs) is sufficient to inhibit DNA synthesis stimulated by pulses of FGF2 and/or ACTH in $\mathrm{G}_{0} / \mathrm{G}_{1}$-arrested $\mathrm{Y} 1$ adrenocortical cells. These results indicate that $c$ Fos and cJun protein induction is an obligatory step in the mechanisms triggered by FGF2 and ACTH to elicit a mitogenic response in Y1 adrenocortical cells. 


\section{Materials and Methods}

\section{Cells and culture procedures}

Y1 mouse adrenocortical carcinoma cells (Yasumura et al. 1966, Schimmer 1981) are a clonal cell line obtained from the American Type Culture Collection (Rockville, MD, USA) in 1973. Frozen stocks were kept in liquid nitrogen and routinely grown in Dulbecco's modified Eagle's medium with heat-inactivated $10 \%$ fetal calf serum (FCS), at $37{ }^{\circ} \mathrm{C}$ in a humidified atmosphere of $5 \% \mathrm{CO}_{2}, 95 \%$ air.

Synthetic ACTH peptides, natural porcine corticotropin $A$ and recombinant bovine FGF2

Synthetic $\mathrm{ACTH}_{39}, \mathrm{ACTH}_{24}$ and $\mathrm{ACTH}_{7-38}$ and natural porcine corticotropin A batch $96 \mathrm{H} 0687(90 \mathrm{U} / \mathrm{mg})$ were purchased from Sigma (St Louis, MO, USA). These Sigma peptide products were analyzed by HPLC and chemically characterized by mass spectrometry and N-terminal sequencing in the laboratory of Prof. L Juliano, at the Escola Paulista de Medicina (UNIFESP, São Paulo), where synthetic ACTH peptides were also synthesized. Bovine recombinant FGF2 was prepared in the laboratory of Prof. A Gambarini, from this Department of Biochemistry.

\section{Phosphorotioate ODNs, antibodies and other reagents}

18-mers of phosphorotioate ODNs were purchased from Gibco BRL (Life Technologies, Inc., São Paulo, Brazil) and Bio-Synthesis, Inc. (Lewisville, TX, USA) with the following sequences: cfos antisense 5'-GGCGTTGAAA CCCGAGAA- $3^{\prime}$ and respective sense; cjun antisense 5'-CGTTTCCATCTTGCAGT-3' and respective sense (Colotta et al. 1992). Rabbit polyclonal antibodies to mouse cFos and JunD proteins were from Santa Cruz Biotechnology Inc. (Santa Cruz, CA, USA); mouse monoclonal anti-bromodeoxyuridine (BrdU) from Amersham Pharmacia Biotech (São Paulo, Brazil); lipofectin from Gibco BRL; and Vectastain Elite ABC kit for immunoperoxidase staining from Vector Labs Inc. (Burlingame, CA, USA).

\section{Protocols of antisense experiments}

Y1 cells were seeded on coverslips and starved in serumfree medium (SFM) for $48 \mathrm{~h}$. Fresh solutions of ODNs $(0 \cdot 2-40 \mu \mathrm{M})$ and lipofectin $(20 \mu \mathrm{g} / \mathrm{ml})$, in SFM, were mixed in equal volumes and incubated for $30 \mathrm{~min}$ to allow for complex formation. Pairs of coverslips were preincubated for 3-4 h in $1 \mathrm{ml}$ fresh SFM containing pre-formed ODN-lipofectin complexes, with ratios of ODN to lipofectin increasing from $0 \cdot 1 \mu \mathrm{M}: 10 \mu \mathrm{g}$ to $20 \mu \mathrm{M}: 10 \mu \mathrm{g}$. At time zero, $100 \mathrm{mU} / \mathrm{ml}$ porcine corticotropin A or $1 \mathrm{nM} \mathrm{FGF2}$ were added to the medium and incubated for $2 \mathrm{~h}$. To test the effect of ODNs in $\mathrm{cFos}$ synthesis the experiment was terminated at $2 \mathrm{~h}$ by rinsing the coverslips with PBS and fixing the cells with $3 \cdot 7 \%$ formaldehyde in PBS for $20 \mathrm{~min}$. On the other hand, when the aim was to estimate the effects of ODNs in S-phase entry by BrdU labeling, the experiment continued until $24 \mathrm{~h}$. In this case, at $2 \mathrm{~h}$ the medium was sucked off and the coverslips were rinsed twice with PBS and re-incubated with fresh SFM containing ODNlipofectin complexes. At $12 \mathrm{~h}, 100 \mu \mathrm{M}$ BrdU was added to the medium and at $24 \mathrm{~h}$ the cells were fixed with methanol and stored in a refrigerator for further processing.

\section{Immunocytochemistry for cFos or JunD protein detection and} $\mathrm{BrdU}$ labeling indices

Nuclear cFos or JunD immune complex was visualized by immunoperoxidase staining using the Vectastain Elite $\mathrm{ABC}$ kit and diaminobenzidine. Nuclei positive for immune complex were stained heavily brown, whereas negative nuclei appeared bluish stained with Harris' hematoxylin and differentiated with a saturated solution of $\mathrm{Li}_{2} \mathrm{CO}_{3}$. Percent of BrdU-labeled nuclei was estimated with anti-BrdU antibody as previously described (Lotfi et al. 1997). Coverslips were randomly coded and 500-600 nuclei per coverslip were blindly counted. Results of independent experiments were pooled and statistically analyzed by Chi-square with 1 degree of freedom.

\section{Results}

Pulses of FGF2 and ACTH stimulate $G_{0} / G_{1}$-arrested $Y 1$ adrenal cells to induce the $c F$ os protein and to enter the S-phase of the cell cycle

Forty-eight hours of serum starvation in SFM caused cell cycle arrest at the $G_{0} / G_{1}$ boundary in $Y 1$ adrenal cells. $\mathrm{G}_{0} / \mathrm{G}_{1}$-arrested $\mathrm{Y} 1$ cells resumed growth upon FCS re-feeding or FGF2 sustained treatment, displaying an onset of DNA synthesis initiation by $8-9 \mathrm{~h}$ (Fig. 1). Short pulses of FGF2 (30 min to $2 \mathrm{~h}$ ) were sufficient to trigger this growth response, exhibiting the same kinetics for S-phase entry (Fig. 1 insert).

Two-hour pulses of synthetic $\mathrm{ACTH}_{39}$ and natural porcine corticotropin A resembled FGF2, inducing cFos protein and stimulating DNA synthesis, but the pattern of the dose-response curves were different (Fig. 2). The dose-response curves for DNA synthesis stimulation and cFos induction by FGF2 were asymptotic and linearly correlated, displaying a coefficient of linear correlation of 0.969 and an $\mathrm{ED}_{50}$ of 6-18 pM (Fig. 2a). On the other hand, $\mathrm{ACTH}_{39}$ and corticotropin A showed maximal stimulation of DNA synthesis at physiological concentrations, whereas the curves for cFos induction were shifted towards higher hormonal concentrations (Fig. 2b and $\mathrm{c}$ ).

We tested the effect of the synthetic inactive ACTH fragment 7-38, a well-known competitive inhibitor of $\mathrm{ACTH}_{39}$ (Li et al. 1978), on DNA synthesis stimulated by both $\mathrm{ACTH}_{39}$ and corticotropin $\mathrm{A}$, under the same 


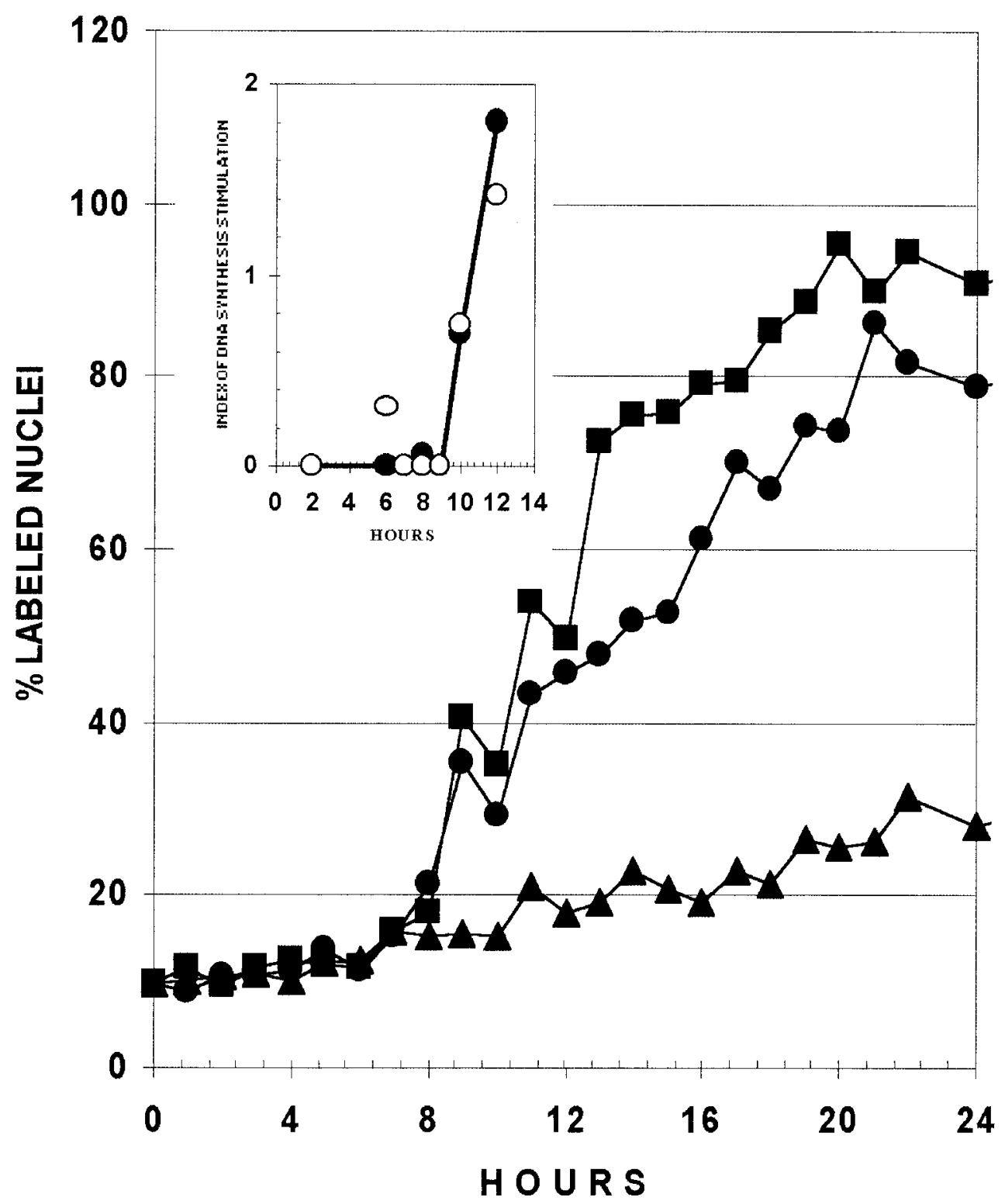

Figure 1 Kinetics of S-phase entry in $\mathrm{G}_{0} / \mathrm{G}_{1}$-arrested $\mathrm{Y} 1$ adrenocortical cell growth stimulated by treatment with FCS or FGF2. FCS (10\%), 1 nM FGF2 and $100 \mu \mathrm{M} \mathrm{BrdU}$ were added to the SFM at zero time; every hour a pair of coverslips was collected for each condition and processed to estimate percent BrdU-labeled nuclei. Results from two independent experiments were pooled and plotted as percent labeled nuclei as a function of time. ( $\boldsymbol{\Delta})$ Control; $(\bullet)$ FGF2; ( $\boldsymbol{(})$ FCS. Insert: kinetics of S-phase entry after a sustained treatment or an initial $2 \mathrm{~h}$ pulse of FGF2. For sustained treatment $(\mathbf{O}), 1 \mathrm{nM}$ FGF2 and $100 \mu \mathrm{M}$ BrdU were added to SFM at zero time. For pulse treatment $(\bigcirc), 1 \mathrm{nM} \mathrm{FGF2} \mathrm{was} \mathrm{added} \mathrm{for} \mathrm{the} \mathrm{first} 2 \mathrm{~h}$, coverslips washed twice with PBS, incubated with fresh SFM and $100 \mu \mathrm{M} \mathrm{BrdU}$ was incorporated in the last hour before collecting coverslips. The index of DNA synthesis stimulation for each time plotted in the graph is given by the expression: (percent labeled nuclei of treated cells minus percent labeled nuclei of untreated control cells) divided by percent labeled nuclei of untreated control cells.

conditions of the assays of Fig. $2 \mathrm{~b}$ and $\mathrm{c}$ respectively. In the range $10^{-12}-10^{-9} \mathrm{M} \mathrm{ACTH}_{39}$ and $10-1000 \mathrm{pg} / \mathrm{ml}$ corticotropin A, stimulation of DNA synthesis was inhibited $60-80 \%$ by $\mathrm{ACTH}_{7-38}$ at $10^{-7} \mathrm{M}$; by itself,
$\mathrm{ACTH}_{7-38}$ at $10^{-7} \mathrm{M}$ had no effect on DNA synthesis. These results suggest that stimulation of DNA synthesis by $\mathrm{ACTH}_{39}$ and corticotropin $\mathrm{A}$, in $\mathrm{G}_{0} / \mathrm{G}_{1}$-arrested $\mathrm{Y} 1$ cells, is mediated by specific ACTH receptors. 

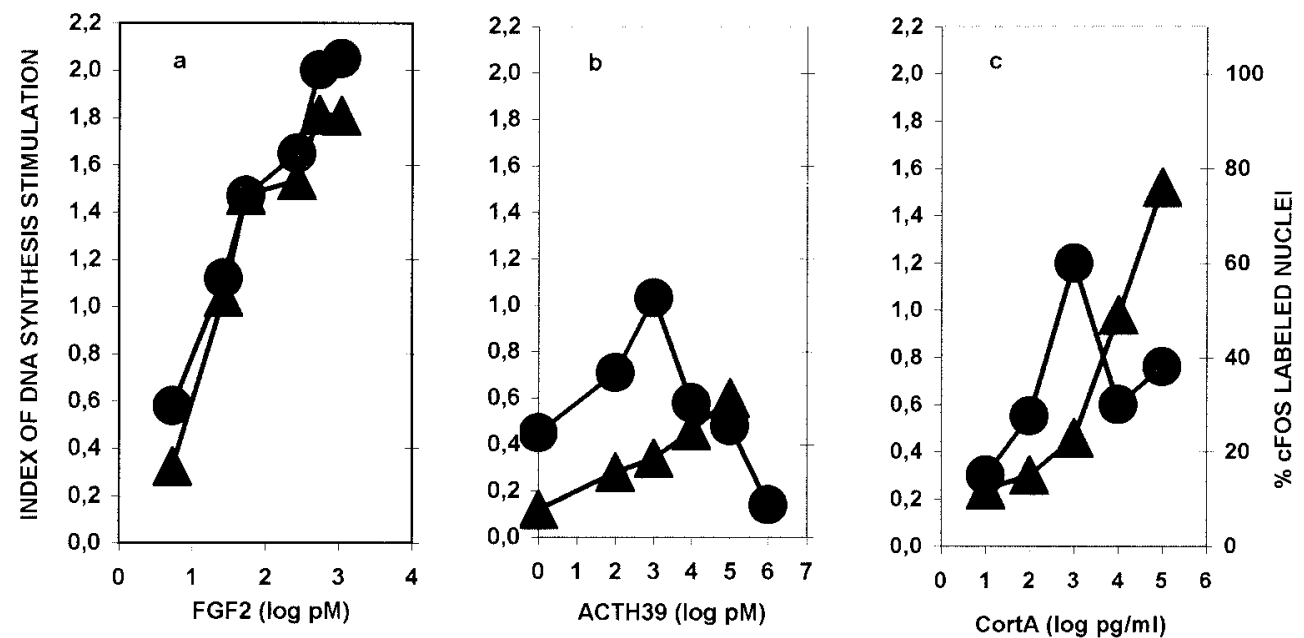

Figure 2 Dose-response curves for DNA synthesis stimulation and cFos protein induction in $\mathrm{G}_{0} / \mathrm{G}_{1}$-arrested $\mathrm{Y} 1$ adrenocortical cells by $2 \mathrm{~h}$ pulses of FGF2, synthetic $A C T H_{39}$ or natural porcine corticotropin A. Y1 cells $G_{0} / G_{1}$-arrested in SFM were pulsed for $2 \mathrm{~h}$ with FGF2, $\mathrm{ACTH}_{39}$ or corticotropin $\mathrm{A}$ at the indicated concentrations. To estimate cFos protein induction $(\mathbf{\Delta})$, a pair of coverslips for each condition was collected at $2 \mathrm{~h}$ and processed to count percent of nuclei stained with the anti-cFos antibody (see Materials and Methods). To estimate DNA synthesis stimulation $(\mathbf{O}), 2 \mathrm{~h}$ pulse-treated $\mathrm{Y} 1$ cells were washed twice with PBS and incubated in fresh SFM; $100 \mu \mathrm{M}$ BrdU was incorporated between 12 and $24 \mathrm{~h}$ and at $24 \mathrm{~h}$ pairs of coverslips for each one of all conditions were collected and processed to count percent BrdU-labeled nuclei. (a) Data from three independent experiments were aggregated to estimate percent labeled nuclei to generate the figures plotted for each point in the curves; 3000-4000 were counted per point. All points in the curves are statistically significant with respect to control $(P<0 \cdot 01$, at least). (b) Five independent experiments; 5000-6500 nuclei counted per point $(P<0 \cdot 01$, at least). (c) Three independent experiments; 3000-3500 nuclei counted per point $(P<0 \cdot 01$, at least). Index of DNA synthesis stimulation as defined in legend of Fig. 1.

Antisense ODNs to cfos and cjun mRNAs block Y1 adrenal cell entry into S-phase stimulated by ACTH and FGF2

The complex $20 \mu \mathrm{M}$ cfos antisense $/ 10 \mu \mathrm{g} / \mathrm{ml}$ lipofectin reduced cFos labeling by $30 \%$, whereas $0 \cdot 1 \mu \mathrm{M}$ cfos antisense $/ 10 \mu \mathrm{g} / \mathrm{ml}$ lipofectin caused $80 \%$ reduction in cFos labeling, (compare data in Table 1). Thus, with a low ODN to lipofectin ratio $(0 \cdot 1 \mu \mathrm{M}: 10 \mu \mathrm{g})$ we achieved a high degree of inhibition of cFos induction. Lipofectin alone and antisense ODN alone had respectively minimal or no effect on cFos labeling (see Fig. 3 and Table 1). The cFos labeling reduction effect of the cfos antisenselipofectin complex was sequence specific: cjun antisense and sense ODNs had no effect (Table 1). In addition, cfos antisense and sense and cjun antisense and sense had no effect on JunD labeling (not shown).

Table 2 shows antisense inhibition of DNA synthesis stimulated by FGF2 and corticotropin A. To analyze the antisense effect we compared pairs of results obtained with an antisense and its respective sense ODN. The complexes of $0 \cdot 1 \mu \mathrm{M}$ ODN: $10 \mu \mathrm{g} / \mathrm{ml}$ lipofectin yielded highly significant inhibition for both cfos and cjun antisense ODNs (Table 2). But the pattern of antisense inhibition was different for FGF2 and corticotropin A (Fig. 4). Combination of both cfos and cjun antisense ODNs was required to completely inhibit DNA synthesis stimulation by FGF2; cfos or cjun antisense ODN alone caused only about $50 \%$ inhibition (Fig. 4a). Table 2 also shows that, in FGF2treated cells, percent BrdU labeling for cfos plus cjun sense ODNs was significantly lower than for lipofectin alone, cfos sense ODN and cjun sense ODNs. However, this unspecific inhibitory effect of the sense ODNs is relatively small when compared with the complete inhibition of DNA synthesis stimulation by FGF2 caused by the combination of cfos and cjun antisense ODNs (Table 2 and Fig. 4a).

On the other hand, DNA synthesis stimulated by corticotropin A was essentially abolished by either cfos or cjun antisense ODNs (Fig. 4b). Lipofectin at $10 \mu \mathrm{g} / \mathrm{ml}$, by itself, caused a significant increase in BrdU labeling of control cultures (Table 2). But this concentration of lipofectin is required to optimize entry of ODNs into the cell, as shown in Fig. 3.

\section{Discussion}

FGF2 and FGF1 are the prototypes of the large family of FGFs (Burgess \& Maciag 1989), presently consisting of 20 members (Nishimura et al. 2000) that are widely expressed in embryo, fetus and adult tissues of vertebrates and invertebrates. It has been recognized for years that forms of 
Table 1 Inhibition of cFos protein induction by cfos-antisense phosphorotioate ODN in $\mathrm{G}_{0} / \mathrm{G}_{1}$-arrested $\mathrm{Y} 1$ adrenocortical cells. $\mathrm{Y} 1$ cells seeded on coverslips, $G_{0} / G_{1}$-arrested in SFM, were incubated for $4 \mathrm{~h}$ with ODN-lipofectin complex, then treated for $2 \mathrm{~h}$ with either $1 \mu \mathrm{g} / \mathrm{ml}$ corticotropin A or $1 \mathrm{nM}$ FGF2, rinsed with PBS and fixed with $3 \cdot 7 \%$ formaldehyde. cFos-stained nuclei were estimated by an immunocytochemical reaction with antibody for the mouse cFos protein. In controls, untreated cells, cFos staining is negligible; $3800-4800$ nuclei and 1060-1550 nuclei were counted for each condition of respectively corticotropin A- and FGF2-treated cells. These results were pooled from two sets of four and two independent experiments for, respectively, corticotropin A and FGF2

\begin{tabular}{|c|c|c|c|c|c|}
\hline & \multirow[b]{2}{*}{ Ratio ODN : lipofectin } & \multicolumn{2}{|l|}{ FGF2 } & \multicolumn{2}{|c|}{ Corticotropin A } \\
\hline & & $\begin{array}{l}\text { Fraction of } \\
\text { cFos-stained } \\
\text { nuclei }\end{array}$ & $\begin{array}{l}\text { Inhibition } \\
\text { of cFos } \\
\text { synthesis (\%) }\end{array}$ & $\begin{array}{l}\text { Fraction of } \\
\text { cFos-stained } \\
\text { nuclei }\end{array}$ & $\begin{array}{l}\text { Inhibition } \\
\text { of cFos } \\
\text { synthesis (\%) }\end{array}$ \\
\hline \multicolumn{6}{|l|}{ ODN + lipofectin } \\
\hline \multirow[t]{2}{*}{ cfos sense } & $20 \mu \mathrm{M}: 10 \mu \mathrm{g} / \mathrm{ml}$ & $0 \cdot 80$ & 0 & $0 \cdot 79$ & $4 \cdot 8$ \\
\hline & $0 \cdot 1 \mu \mathrm{M}: 10 \mu \mathrm{g} / \mathrm{ml}$ & ND & ND & $0 \cdot 91$ & 0 \\
\hline \multirow{2}{*}{ cfos antisense } & $20 \mu \mathrm{M}: 10 \mu \mathrm{g} / \mathrm{ml}$ & $0 \cdot 55$ & 31 & $0 \cdot 41$ & 51 \\
\hline & $0 \cdot 1 \mu \mathrm{M}: 10 \mu \mathrm{g} / \mathrm{ml}$ & ND & ND & $0 \cdot 17$ & 80 \\
\hline cfos sense + cjun sense & $20 \mu \mathrm{M}: 10 \mu \mathrm{g} / \mathrm{ml}$ & $0 \cdot 79$ & $1 \cdot 3$ & $0 \cdot 86$ & 0 \\
\hline cfos antisense + cjun antisense & $20 \mu \mathrm{M}: 10 \mu \mathrm{g} / \mathrm{ml}$ & $0 \cdot 54$ & 33 & $0 \cdot 62$ & 31 \\
\hline Lipofectin & $0: 10 \mu \mathrm{g} / \mathrm{ml}$ & $0 \cdot 88$ & 0 & $0 \cdot 76$ & $8 \cdot 4$ \\
\hline- & $0: 0$ & $0 \cdot 80$ & 0 & $0 \cdot 83$ & 0 \\
\hline
\end{tabular}

ND: not done.

FGF exist as local paracrine and autocrine regulators of basic biological processes like mitogenesis, cellular differentiation, angiogenesis and tissue repair in the adult organism (Burgess \& Maciag 1989). In addition, reports over the last few years have involved FGF proteins and their respective set of receptors in mechanisms of classical epithelial-mesenchymal interactions, underlying differentiation and organogenesis in the embryo (Jung et al. 1999, Metzger \& Krasnow 1999, Meyers \& Martin 1999, Miralles et al. 1999). For instance, FGF2 has long been considered a candidate to participate in the control of fetal development of adrenal glands and, also, of growth and function of the adult adrenal cortex (Mesiano et al. 1991).

Here we show that FGF2 elicits a strong mitogenic response in $G_{0} / G_{1}$-arrested $Y 1$ adrenocortical cells, measured by BrdU labeling (Fig. 1), that linearly correlates with an early cFos induction (Fig. 2), implying a causeeffect relationship. We previously reported (Lotfi et al. 1997) that short pulses of ACTH, but not sustained treatment, resemble FGF2, inducing cFos and stimulating DNA synthesis in $G_{0} / G_{1}$-arrested $Y 1$ cells. In sharp contrast with FGF2, ACTH dose-response curves for cFos induction and DNA synthesis stimulation are not correlated (Fig. $2 b$ and c), suggesting that the cFos protein might not be a mediator in the growth response promoted by this hormone. To test whether induction of fos and jun genes are necessary for cell entry into S-phase stimulated by ACTH and FGF2, we blocked cFos and cJun protein synthesis with antisense phosphorotioate ODNs.

In principle, the antisense ODN technique affords the highest possible selectivity for blocking mRNA translation, thanks to the specificity of Watson-Crick base pairing between the antisense ODN and its respective
mRNA. Phosphorotioate ODNs are resistant to cellular nucleases and association of ODN with cationic liposomes promotes cell entry, rendering the antisense ODN technique an efficacious approach to suppress synthesis of specific proteins (Wagner 1994). We tested cfos and cjun antisense and sense 18-mers sequences that have worked well for others to suppress cFos and cJun expression (Colotta et al. 1992). In Y1 adrenocortical cells, this cfos antisense ODN efficaciously inhibited cFos protein synthesis (Table 1 and Fig. 3). We have not directly monitored cJun protein synthesis, but presumably cJun synthesis was also inhibited by an antisense effect with the cjun antisense ODN used. In addition, cfos and cjun antisense ODNs blocked DNA synthesis stimulation by FGF2 and ACTH (Table 2 and Fig. 4).

Others (Guvakova et al. 1995) have reported that phosphorotioate ODNs can bind FGF2 preventing its association to receptors and, consequently, inhibiting its activity. This non-specific interaction between ODNs and FGF2 is unlikely to be important in our experiments. First, except for the cfos antisense, all other ODNs do not inhibit cFos induction by FGF2 (Table 1). Secondly, cfos or cjun sense had no effect on DNA synthesis stimulation by FGF2 (Table 2). Thirdly, in our laboratory, several sense phosphorotioate ODNs for cyclin D1 and c-myc mRNAs were tested and none of them have shown inhibition of FGF2 activity (A P Lepique, T T Schwindt \& H A Armelin, unpublished observations). Fourthly, in our procedures ODNs are first complexed with lipofectin before addition to the culture medium (see Materials and Methods); under these conditions ODNs are trapped in ODN-lipofectin complexes and are unlikely to be available for interaction with FGF2. Altogether, these results suggest that we are efficaciously blocking both cFos 


\section{2h ACTH}

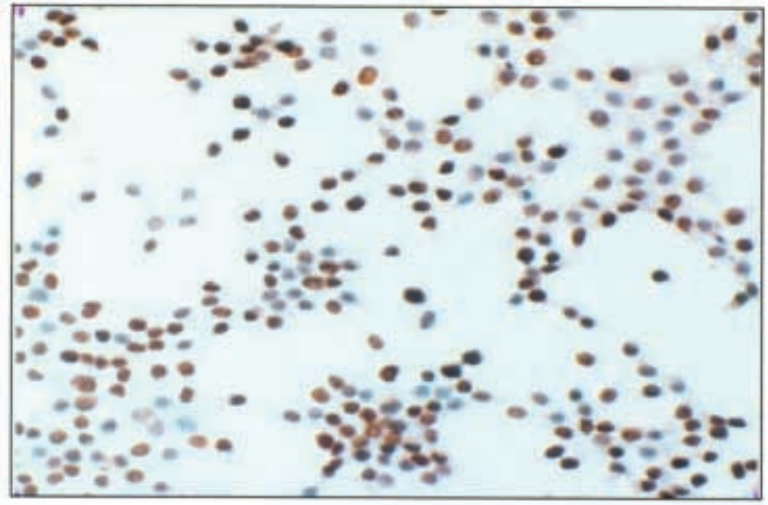

\section{2h ACTH + Sense/Lipofectin}

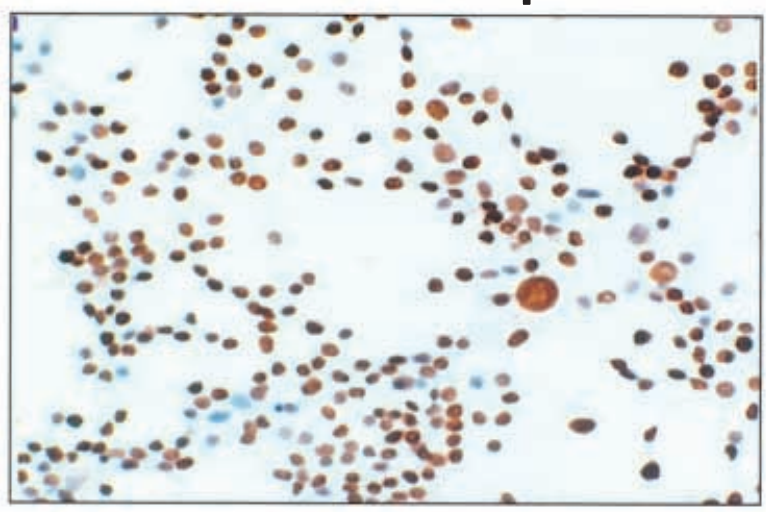

\section{$2 \mathrm{~h} \mathrm{ACTH}+0.1 \mu \mathrm{M}$ Antisense}

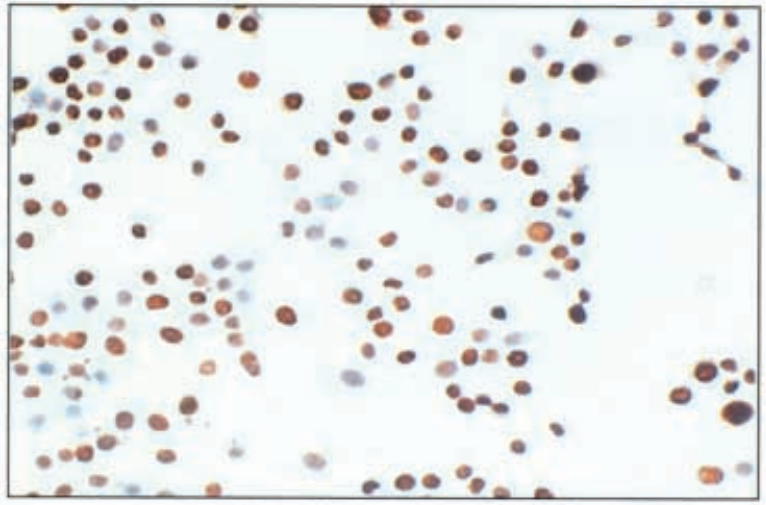

Untreated Control

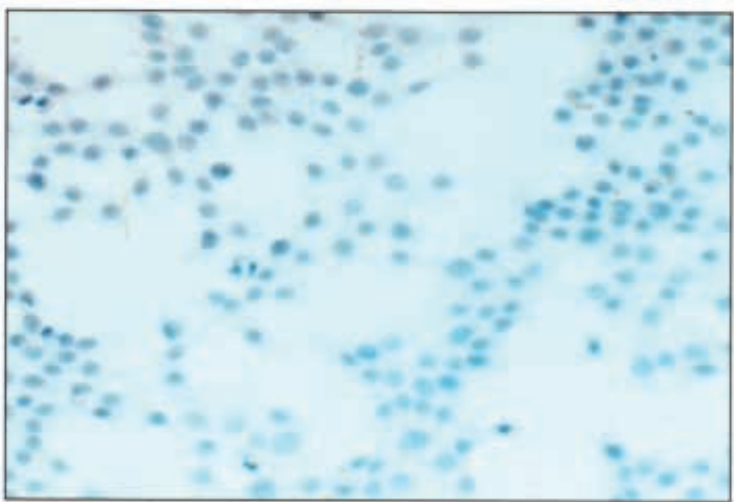

\section{2h ACTH + Antisense/Lipofectin}

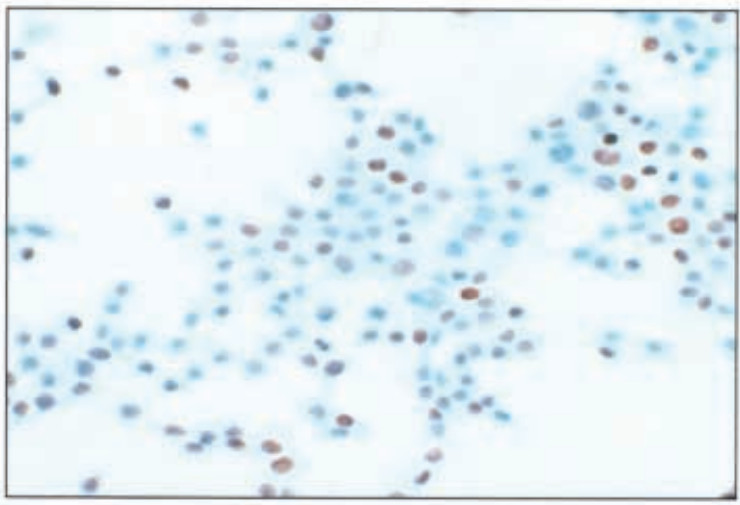

Figure 3 Inhibition of cFos protein induction by cfos antisense phosphorotioate ODN in $\mathrm{G}_{0} / \mathrm{G}_{1}$-arrested $\mathrm{Y} 1$ adrenocortical cells: specificity of the antisense ODN and requirement for lipofectin. Protocols are described in the legend to Table 1 and staining procedures in Materials and Methods. Ratio of ODN to lipofectin for complex formation: $0 \cdot 1 \mu \mathrm{M}: 10 \mu \mathrm{g} / \mathrm{ml}$ respectively. Magnification: $\times 250$. 
Table 2 Inhibitory effects of c-fos and c-jun antisense phosphorotioate ODNs on DNA synthesis stimulated by $2 \mathrm{~h}$ pulses of respectively FGF2 and corticotropin $A$ in $G_{0} / G_{1}$-arrested $Y 1$ adrenocortical cells. $Y 1$ cells seeded on coverslips and $G_{0} / G_{1}$-arrested in SFM for 48 h, were incubated for $4 \mathrm{~h}$ with ODN-lipofectin complex (0.1 $\mu \mathrm{M}$ ODN : $10 \mu \mathrm{M}$ lipofectin), before treatment with $1 \mu \mathrm{g} / \mathrm{ml}$ corticotropin A and $1 \mathrm{nM}$ FGF2 between 0 and $2 \mathrm{~h}$. After treatment, coverslips were rinsed and incubated in fresh SFM plus the respective ODN-lipofectin complex. BrdU $(100 \mu \mathrm{M})$ was incorporated between 12 and $24 \mathrm{~h}$. At $24 \mathrm{~h}$ cells were fixed and processed to estimate percent BrdU-labeled nuclei. Index of DNA synthesis stimulation as defined in legend of Fig. 1

\section{FGF2 $^{\text {a }}$}

\begin{tabular}{ll}
\hline BrdU-labeled nuclei (\%) \\
\hline Treated & Untreated \\
\hline
\end{tabular}

ODN+lipofectin

cfos sense

cfos antisense

cjun sense

cjun antisense

cfos sense+cjun sense

cfos antisense + cjun antisense

Lipofectin

\begin{tabular}{l} 
Index of DNA \\
synthesis \\
stimulation \\
\hline
\end{tabular}

\section{$57 \cdot 6$}

$45 \cdot 0$

$61 \cdot 7$

$48 \cdot 7$

$50 \cdot 7$

$31 \cdot 5$

$58 \cdot 4$

$63 \cdot 1$

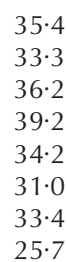

\section{Corticotropin $A^{b}$}

\begin{tabular}{|c|c|c|}
\hline \multicolumn{2}{|c|}{ BrdU-labeled nuclei (\%) } & \multirow{2}{*}{$\begin{array}{l}\text { Index of DNA } \\
\text { synthesis } \\
\text { stimulation }\end{array}$} \\
\hline Treated & Untreated & \\
\hline $55 \cdot 1$ & $39 \cdot 7$ & $0 \cdot 40$ \\
\hline $38 \cdot 8$ & $44 \cdot 9$ & 0 \\
\hline $58 \cdot 1$ & $44 \cdot 2$ & $0 \cdot 31$ \\
\hline $45 \cdot 9$ & $45 \cdot 3$ & $0 \cdot 01$ \\
\hline $64 \cdot 0$ & $43 \cdot 7$ & $0 \cdot 46$ \\
\hline $36 \cdot 2$ & $44 \cdot 6$ & 0 \\
\hline $58 \cdot 5$ & $42 \cdot 3$ & $0 \cdot 38$ \\
\hline $60 \cdot 6$ & $36 \cdot 0$ & $0 \cdot 68$ \\
\hline
\end{tabular}

a,$b$ are pools of two different sets of two independent experiments; 2200-2700 nuclei were counted for each condition.
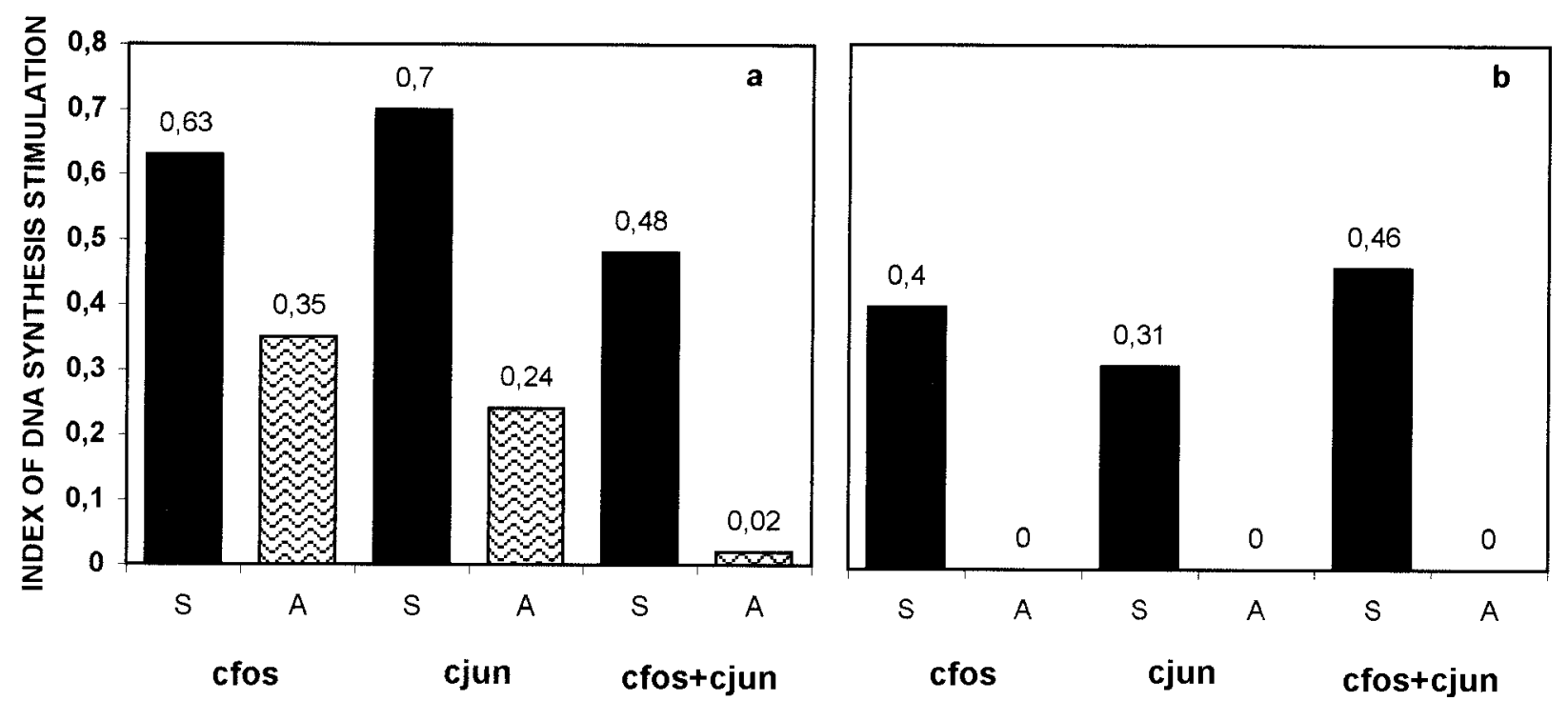

Figure 4 Inhibition of DNA synthesis stimulation by cfos and/or cjun antisense phosphorotioate ODN in $G_{0} / G_{1}$-arrested $Y 1$ adrenocortical cells stimulated by $2 \mathrm{~h}$ pulses of respectively FGF2 and natural porcine corticotropin A. The indices of DNA synthesis stimulation shown in the histograms are from Table 2. (a) Y1 cells stimulated with $1 \mathrm{nM}$ FGF2 and (b) Y1 cells stimulated with $1 \mu \mathrm{g} / \mathrm{ml}$ porcine corticotropin A. S and A stand for respectively sense and antisense ODN. All differences between $\mathrm{S}$ and $\mathrm{A}$ are statistically significant $(P<0 \cdot 01$, at least). Protocols are summarized in the legend of Table 2.

protein induction and DNA synthesis stimulation by an antisense mechanism.

cfos or cjun antisense ODNs are sufficient to completely abolish stimulation of DNA synthesis by ACTH, but not by FGF2 (Fig. 4). Only a combination of both cfos and cjun antisense ODNs can extinguish DNA synthesis stimulated by FGF2 in $G_{0} / G_{1}$-arrested Y1 cells (Fig. 4). These results are not surprising, since Kovary \& Bravo (1991b) have shown that only micro-injections of combinations of antibodies against Fos and Jun proteins can block $\mathrm{G}_{1}$-phase traversing in $\mathrm{G}_{0}$-arrested mouse $3 \mathrm{~T} 3$ fibroblasts growth stimulated with serum.

Thus, the results of our antisense experiments support the notion that the induction of cFos and cJun proteins is a necessary step in the triggering mechanisms by which ACTH or FGF2 drives $G_{0} / G_{1}$-arrested Y1 cells to enter 
the S-phase. Consequently, FGF2 and ACTH receptors must activate pathways that converge to $\mathrm{cFos}$ and cJun induction. The Ras-Raf-MEK-ERK cascade of kinases is a highly conserved pathway that integrates mitogenic signals initiated in tyrosine kinase and $G$ protein-coupled receptors (Gutkind 1998). Actually, in $G_{0} / G_{1}$-arrested $Y 1$ cells, FGF2 rapidly and strongly triggers transient phosphorylation of ERK1/2, whereas $\mathrm{ACTH}_{39}$ is a poor ERK1/2 activator. But, the MEK1 inhibitor, PD98059 $(50 \mu \mathrm{M})$, inhibits cFos induction and DNA synthesis stimulation by both $\mathrm{ACTH}_{39}$ and FGF2, suggesting that ERK1/2 activation mediates the strong and the weak mitogenic effect of, respectively, FGF2 and $\mathrm{ACTH}_{39}$ (Lotfi et al. 1997, 2000). In addition, we have previously reported that the weak mitogenic effect of $\mathrm{ACTH}_{39}$ does not depend on the cAMP/PKA pathway (Lotfi et al. 1997).

On the other hand, one must keep in mind that ACTH behaves as a strong anti-mitogen in cultures of adrenocortical cells from a variety of species (Hornsby 1985). How can we mechanistically reconcile this strong antimitogenic action of ACTH with its weak mitogenic effect that we are focusing on in this report? In Y1 adrenal cells, this ACTH anti-mitogenic effect is dependent on the cAMP/PKA pathway (Masui \& Garren 1971, Rae et al. 1979, Lotfi et al. 1997). But the mechanisms underlying ACTH anti-mitogenic effects are still essentially unknown. We recently observed three cAMP/PKAdependent effects of ACTH concurring to block Y1 cell cycle at $\mathrm{G}_{1}$-phase, namely: (i) degradation of the cMyc protein (Lepique et al. 2000); (ii) dephosphorylation/ deactivation of the Akt/PKB enzyme (Forti \& Armelin 2000); and (iii) induction of the p27 Kip1 protein, an inhibitor of cyclin-dependent kinases (T. Schwindt, F. Forti \& H. Armelin, unpublished observations). In conclusion, ACTH receptors initiate signals leading to dual effects promoting and inhibiting cell cycle progress. It remains to be explained how these antagonistic effects of ACTH are balanced to regulate growth and function of the adrenal cortex. Studies on the interactions between ACTH and FGF2 in $G_{0} / G_{1}$-arrested $Y 1$ adrenocortical cells are useful to elucidate circuits that integrate signals initiated in respectively ACTH receptors and FGF2 receptors that should be relevant to the mechanisms underlying regulation of the $G_{0} \rightarrow G_{1} \rightarrow S$ transition in adrenal cell cycle.

\section{Acknowledgements}

This work was supported by grants from FAPESP (Fundação de Amparo à Pesquisa do Estado de São Paulo) and $\mathrm{CNPq}$ (Conselho Nacional de Desenvolvimento Cientí fico e Tecnológico) to HA A. CFPL was a postdoctoral fellow of FAPESP. We are indebted to Prof. Luiz Juliano (Escola Paulista de Medicina, UNIFESP, São Paulo) for first rate chemical analysis of commercial ACTH peptides and natural porcine corticotropin $\mathrm{A}$, and also for the synthesis of $\mathrm{ACTH}_{39}, \mathrm{ACTH}_{24}$ and $\mathrm{ACTH}_{7-38}$. We thank Prof. Angelo Gambarini (Departamento de Bioquímica, Instituto de Química, Universidade de São Paulo) for generous provision of bovine recombinant FGF2.

\section{References}

Angel P \& Karin M 1991 The role of Jun, Fos and the AP-1 complex in cell-proliferation and transformation. Biochimica et Biophysica Acta 1072 129-157.

Armelin HA, Lotfi CFP \& Lepique AP 1996 Regulation of growth by ACTH in the Y-1 line of mouse adrenocortical cells. Endocrine Research 22 373-383.

Burgess WH \& Maciag T 1989 The heparin-binding fibroblast growth factor family of proteins. Annual Review of Biochemistry $\mathbf{5 8}$ $575-606$

Colotta F, Polentarutti N, Sironi M \& Mantovani A 1992 Expression and involvement of $\mathrm{c}$-fos and c-jun protooncogenes in programmed cell-death induced by growth factor-deprivation in lymphoid-cell lines. Journal of Biological Chemistry 267 18278-18283.

Cook SJ, Aziz N \& McMahon M 1999 The repertoire of Fos and Jun proteins expressed during the $G_{1}$ phase of the cell cycle is determined by the duration of mitogen-activated protein kinase activation. Molecular Cell Biology 19 330-341.

Forti FL \& Armelin HA 2000 ACTH inhibits a Ras-dependent anti-apoptotic and mitogenic pathway in mouse Y1 adrenocortical cells. Endocrine Research 26 (In Press).

Gutkind JS 1998 The pathways connecting G protein-coupled receptors to the nucleus through divergent mitogen-activated protein kinase cascades. Journal of Biological Chemistry 273 1839-1842.

Guvakova MA, Yabukov LA, Vlodavsky I, Tonkinson JL \& Stein CA 1995 Phosphorotioate oligos bind to basic FGF, inhibit its binding to cell surface receptors, and remove it from low affinity binding-sites on extra-cellular matrix. Journal of Biological Chemistry $2702620-2627$.

Holt JT, Gopal TV, Moulton AD \& Nienhuis AW 1986 Inducible production of c-fos antisense RNA inhibits 3T3 cell proliferation. PNAS 83 4794-4798.

Hornsby PJ 1985 Regulation of adrenocortical cell proliferation in culture. Endocrine Research 10 259-281.

Jung J, Zheng M, Goldfarb M \& Zaret KS 1999 Initiation of mammalian liver development from endoderm by fibroblast growth factors. Science 284 1998-2003.

Kimura E \& Armelin HA 1990 Phorbol ester mimics ACTH action in corticoadrenal cells stimulating steroidogenesis, blocking cell cycle, changing cell shape and inducing c-fos proto-oncogene expression. Journal of Biological Chemistry 265 3518-3521.

Kimura E, Sonobe MHH, Armelin MCS \& Armelin HA 1993 Induction of FOS and JUN proteins by adrenocorticotropin and phorbol ester but not by $3^{\prime}, 5^{\prime}$-cyclic adenosine monophosphate derivatives. Molecular Endocrinology 7 1463-1471.

Kovary K \& Bravo R 1991a Expression of different Jun and Fos proteins during the $G_{0}$ to $G_{1}$ transition in mouse fibroblasts: 'in vitro' and 'in vivo' associations. Molecular Cell Biology 11 2451-2459.

Kovary K \& Bravo R $1991 b$ The Jun and Fos protein families are both required for cell cycle progression in fibroblasts. Molecular Cell Biology 11 4466-4472.

Lepique AP, Forti FL, Moraes MS \& Armelin HA 2000 Signal transduction in $\mathrm{G}_{0} / \mathrm{G}_{1}$-arrested mouse $\mathrm{Y} 1$ adrenocortical cells stimulated by ACTH and FGF2. Endocrine Research $\mathbf{2 6}$ (In Press). 
Li CH, Chung D, Yamashiro D \& Lee CY 1978 Isolation, characterization and synthesis of a corticotropin-inhibiting peptide from human pituitary glands. PNAS 75 4306-4309.

Lotfi CFP, Todorovic Z, Armelin HA \& Schimmer BP 1997 Unmasking a growth-promoting effect of the ACTH in Y1 mouse adrenocortical tumor cells. Journal of Biological Chemistry 272 29886-29891.

Lofti CFP, Costa ET, Schwindt TT \& Armelin HA 2000 Role of ERK/MAP kinase in mitogenic interaction between ACTH and FGF2 in mouse Y1 adrenocortical tumor cells. Endocrine Research 26 (In Press).

Masui H \& Garren LD 1971 Inhibition of a replication in functional mouse adrenal tumor cells by ACTH mediated by cAMP. PNAS 68 3206-3211.

Mesiano S, Mellon SH, Gospodarowicz D, DiBlasio AM \& Jaffe RB 1991 Basic FGF expression in regulated by corticotropin in the human fetal adrenal - a model for adrenal growth regulation. PNAS 88 5428-5432.

Metzger RJ \& Krasnow MA 1999 Development genetic control of branching morphogenesis. Science 284 1635-1639.

Meyers EN \& Martin GR 1999 Differences in left-right axis pathways in mouse and chick: functions of FGF8 and SHH. Science $\mathbf{2 8 5}$ 403-406.

Miralles F, Czernichow P, Ozaki K, Itoh N \& Scharfman R 1999 Signaling through FGF receptor $2 \mathrm{~b}$ plays a key role in the development of the exocrine pancreas. PNAS 96 6267-6272.
Nishikura K \& Murray JM 1987 Antisense RNA of protooncogene c-fos blocks renewed growth of quiescent 3T3 cells. Molecular Cell Biology 7 639-649.

Nishimura T, Nakatake Y, Konishi M \& Itoh N 2000 Identification of a novel FGF, FGF21, preferentially expressed in the liver. Biochimica et Biophysica Acta 1492 203-206.

Rae PA, Gutmann NS, Tsao J \& Schimmer BP 1979 Mutations in cAMP-dependent protein kinase and ACTH-sensitive adenylate cyclase affect adrenal steroidogenesis. PNAS 76 1896-1900.

Riabowol KT, Vosatka R, Ziff EB, Lamb NJ \& Feramisco JR 1988 Microinjection of fos-specific antibodies blocks DNA synthesis in fibroblast cells. Molecular Cell Biology 8 1670-1676.

Schimmer BP 1981 The adrenocortical tumor cell line, Y-1. In Functionally Differentiated Cell Lines, pp 61-92. Ed. G Sato. New York: Alan R Liss, Inc.

Wagner RW 1994 Gene inhibition using antisense oligodeoxynucleotides. Nature 372 333-335.

Yasumura Y, Buonassissi Y \& Sato G 1966 Clonal analysis of differentiated function in animal cell culture. I. Possible correlated maintenance of differentiated function and the diploid karyotype. Cancer Research 26 529-535.

Received 26 October 2000 Accepted 10 November 2000 